\title{
The microbiological quality of water in fish spas with Garra rufa fish, the Netherlands, October to November 2012
}

F M Schets (ciska.schets@rivm.nl) ${ }^{1}$, H H van den Berg' ${ }^{1}$, R de Zwaan ${ }^{2}$, D van Soolingen², A M de Roda Husman ${ }^{1}$

1. National Institute for Public Health and the Environment, Centre for Zoonoses and Environmental Microbiology, Bilthoven, the Netherlands

2. Centre for Infectious Diseases and Perinatal Screening, Bilthoven, the Netherlands

Schets FM, van den Berg HH, de Zwaan R, van Soolingen D, de Roda Husman AM. The microbiological quality of water in fish spas with Garra rufa fish,

the Netherlands, October to November 2012. Euro Surveill. 2015;20(19):pii=21124. Available online: http://www.eurosurveillance.org/ViewArticle.

aspx?Articleld $=21124$

Article submitted on 04 April 2014 / published on 14 May 2015

In fish spas, clients may submerge their hands, feet or whole body in basins with Garra rufa fish, for dead skin removal. Skin infections may result from using these spas, transmitted from fish to clients, through either fish or water, or from client to client. The microbiological water quality was determined in 24 fish spas in 16 companies in the Netherlands through analysis of a single water sample per fish spa. Water samples were tested for the presence of Aeromonas spp., Vibrio spp., Pseudomonas aeruginosa, nontuberculous mycobacteria, and faecal indicator bacteria by using standard culture methods. The majority of the examined fish spas contained Aeromonas spp. $(\mathrm{n}=24), P$. aeruginosa $(n=18)$, Vibrio spp. $(n=16)$ including $V$. cholerae non$0_{1} / 0_{139}$ and $V$. vulnificus, and several rapid growing Mycobacterium spp. $(\mathrm{n}=23)$ including $M$. fortuitum, $M$. conceptionense, M. abscessus and M. chelonae. Faecal contamination of the fish spa water was low. Based on the detected concentrations of Aeromonas spp., Vibrio spp., and $P$. aeruginosa, the detected Mycobacterium spp., and the health implications of these bacteria, the health risk from using fish spas is considered limited for healthy people with an intact skin and no underlying disease.

\section{Introduction}

Originating from Turkey, fish spas are increasingly popular and available throughout the world. In fish spas, clients submerge their feet, hands, or their whole body, in basins with Garra rufa fish that nibble dead and thickened skin from the submerged body parts during a 15 to 30 minutes treatment. Garra rufa are small toothless fish that belong to the carp family (Cyprinidae). The use of fish spas is mostly considered a cosmetic and relaxing treatment, but it is also offered to relieve skin disorders such as eczema and psoriasis [1-3]. Studies performed in Turkey and Austria suggested a beneficial effect of fish spa therapy, or ichthyotherapy, on psoriasis. However, several factors could have contributed to this outcome, including limited follow-up of patients, selenium in the therapy water, and simultaneous ultraviolet light A (UVA) treatment $[2,3]$.

Since the same water and fish are used for several simultaneous and subsequent clients, and the fish are potential carriers of pathogens, the most important health risk from fish spas is the possible transmission of infections [1]. The water temperature in fish spas is kept at $25-30^{\circ} \mathrm{C}$ thus providing opportunities for many bacteria to thrive. Pathogens may be transmitted from fish to man, from water to man, and from man to man with water and/or fish. An appropriate water quality is important to reduce the risk of infection for clients. Conventional water treatment and disinfection are, however, not possible, because these processes would kill the fish [1]. Commonly, the water is filtered, but most applied filters do not remove micro-organisms and those that do, have little effect on micro-organisms in biofilms or on the fish skin [1]. Continuous partly refreshment of the water results in dilution of the microbial contamination and may have a beneficial effect on water quality when no fresh contamination is introduced. However, in daily practice, fish spas are continuously re-contaminated while in use [1].

The handling of fish, and keeping fish in crowded aquaria, may lead to chronic stress, reduced fish health, and poor fish immunity [4]. Apparently healthy fish may carry (human) pathogens without having visible symptoms. When such fish are exposed to unfavourable conditions, outbreaks of infectious diseases may occur among the fish, resulting in an increased number of waterborne bacteria in the spas, with an accompanying increased zoonotic risk of transmission to humans [5]. Recently, Aeromonas sobria was implicated as the cause of massive die-off in Garra rufa at 
a breeding farm in Slovakia [6], and a batch of ill Garra rufa in England appeared to be contaminated with Streptococcus agalactiae [7].

Examination of several batches of Garra rufa that entered the United Kingdom (UK) from Indonesia and several other Asiatic countries, demonstrated the presence of, among others, Aeromonas spp., Vibrio spp., Mycobacterium senegelense and Streptococcus agalactiae. All of these bacteria are capable of causing disease in humans [7].

Concerns about possible transmission of infections from fish spas to humans have led to the publication of guidance [1] and risk assessment documents [8] in the UK and France respectively, and a negative advice against starting new companies or continuation of existing companies offering fish spa treatment in Belgium [9]. Fish spas have been banned in some provinces in Germany due to animal welfare considerations, and the German veterinary authority has drafted a requirements document for new fish spas [10]. Animal welfare and hygiene considerations have resulted in a ban of fish spas in several states in the United States and some provinces in Canada [1].

In this study, the water in a random selection of fish spas throughout the Netherlands was tested for the presence of Aeromonas spp., Vibrio spp., Pseudomonas aeruginosa, nontuberculous mycobacteria (NTM) and the faecal indicator bacteria Escherichia coli and intestinal enterococci, to assess the microbiological water quality. Possible implications for public health are discussed.

\section{Materials and methods}

\section{Recruitment of participants and sampling of fish spas}

A random selection of 25 companies that offered fish spa treatment was asked by letter to participate in the study in September 2012.

At each participating company, one fish spa was sampled, however, when several types of fish spas were present (hand, foot, body), one spa of each type was sampled. Whenever there was visible dirt on the fish spa walls, Enviro Swabs (3M) were used to take swab samples from these walls. Water samples of $1.5 \mathrm{~L}$ were taken according to ISO 19458:2006. All samples were transported to the laboratory in insulating containers with melting ice and analysed within 24 hours from sampling. Samples were taken in October and November 2012, during opening hours, almost always unannounced, and at different times during the sampling days.

\section{Sample analyses}

All water samples were examined for the number of Escherichia coli (in 10, and $40 \mathrm{~mL}$ volumes), intestinal enterococci (in 10, and $40 \mathrm{~mL}$ volumes), Aeromonas spp. (in 0.1 , and $1.0 \mathrm{~mL}$ volumes), and Vibrio spp. (in $0.1,1,10$, and $40 \mathrm{~mL}$ volumes) by membrane filtration of appropriate volumes of the samples according to ISO 9308-1:2000 (Rapid Test), ISO 7899-2:2000, Havelaar et al. [11], and incubation of the membrane filters on Thiosulphate Citrate Bile salts Sucrose agar (TCBS; Tritium Microbiologie, Eindhoven, the Netherlands) at $36 \pm 2{ }^{\circ} \mathrm{C}$ for $24 \pm 4$ hour, respectively. Vibrio characteristic colonies on TCBS were subcultured onto Trypton Soy Agar (TSA; Oxoid, Badhoevedorp, the Netherlands) and incubated at $36 \pm 2{ }^{\circ} \mathrm{C}$ for $20-24$ hours.

From each sample, a maximum of five presumptive Aeromonas spp., and ten presumptive Vibrio spp. (five blue and five green colonies) were confirmed by using Matrix Assisted Laser Desorption Ionization Time of Flight mass spectrometry (MALDI-TOF) [12]. Occasionally, e.g. when large amounts of background flora were present, presumptive $E$. coli and enterococci were confirmed by MALDI-TOF.

$P$. aeruginosa was enumerated in $100 \mathrm{~mL}$ samples by using Pseudalert (IDEXX Laboratories Inc., Westbrook, ME, US) according to the manufacturer's instructions. A most probable number (MPN) table (provided by the manufacturer) was used to determine the $P$. aeruginosa concentration in the samples. Occasionally, the content of a fluorescent well was subjected to confirmation by MALDI-TOF.

For analysis of NTM, $1 \mathrm{~L}$ water samples were decontaminated by 30 minutes incubation with $0.005 \%$ cetylpyridinium chloride (CPC) at room temperature. Two $0.5 \mathrm{~L}$ fractions of the decontaminated samples were filtered through $0.45 \mu \mathrm{m}$ pore size black membrane filters (Millipore, Amsterdam, the Netherlands). Subsequently, the two membrane filters were washed with $300 \mathrm{~mL}$ sterile distilled water, dissected, and placed onto the moderately selective sides $(7 \mathrm{H} 10)$ and the antimicrobial-supplemented highly selective sides ( $\left.7 \mathrm{H}_{11}\right)$ of two Middlebrook $7 \mathrm{H}_{10} / 7 \mathrm{H}_{11}$ agar bi-plates (Becton Dickinson, Erembodegem, Belgium). The plates were sealed in air permeable bags; one plate was incubated at $30^{\circ} \mathrm{C}$ and the other at $36^{\circ} \mathrm{C}$ for up to three weeks, with weekly inspection for growth of colonies with characteristic morphology. Presumptive mycobacterial colonies were picked, to a total of 10 per sample, and subcultured onto Middlebrook $7 \mathrm{H}_{10}$ agar plates supplemented with Delvocid (Tritium Microbiologie, Eindhoven, the Netherlands) at $30^{\circ} \mathrm{C}$ and $36^{\circ} \mathrm{C}$, and identified by sequencing of the $r p o B$ gene $[13,14]$.

Water temperature of all samples was determined on site, whereas $\mathrm{pH}$, turbidity, and conductivity were determined in the laboratory, using standard laboratory equipment. 
Physical-chemical and microbiological parameters in the water of 24 fish spas in 16 companies, the Netherlands, October-November 2012

\begin{tabular}{|c|c|c|c|c|c|c|c|c|c|}
\hline $\begin{array}{l}\text { Sample date } \\
(2012)\end{array}$ & Company & Spa type and capacity & $\begin{array}{c}\text { Water } \\
\text { temperature } \\
\left({ }^{\circ} \mathrm{C}\right)\end{array}$ & $\mathrm{pH}$ & $\begin{array}{l}\text { Conductivity } \\
(\mu \mathrm{S} / \mathrm{cm})\end{array}$ & $\begin{array}{c}\mathrm{IE} \\
(\mathrm{n} / 100 \mathrm{~mL})\end{array}$ & $\begin{array}{l}\text { Aeromonas } \\
\text { spp. } \\
(\mathrm{n} / 100 \mathrm{~mL})\end{array}$ & $\begin{array}{l}\text { Vibrio spp. } \\
(\mathrm{n} / 100 \mathrm{~mL})\end{array}$ & $\begin{array}{c}\text { Pseudomonas } \\
\text { aeruginosa } \\
(\mathrm{MPN} / 100 \mathrm{~mL})\end{array}$ \\
\hline $220 \mathrm{ct}$ & A & Foot, 1 person & 29.5 & 8.43 & 451 & 0 & 30,000 & 0 & 124 \\
\hline 22 Oct & A & Foot, 1 person & 29.5 & 7.72 & 449 & 1 & 19,500 & 0 & 137 \\
\hline $220 \mathrm{ct}$ & $\mathrm{B}$ & Foot, 2 persons & 28.1 & 8.19 & 379 & 0 & 24,000 & 0 & 42 \\
\hline $220 \mathrm{ct}$ & $\mathrm{C}$ & Foot, 2 persons & 29.0 & 8.14 & 552 & 1 & 82,000 & 411 & 178 \\
\hline $300 \mathrm{ct}$ & $\mathrm{D}$ & Foot, 4 persons & 27.8 & 8.03 & 483 & 2 & 4,036 & 648 & 59 \\
\hline $300 \mathrm{ct}$ & $E$ & Body, 1 person & 31.2 & 8.49 & 294 & 0 & 32 & 5.4 & $<1$ \\
\hline $300 \mathrm{ct}$ & $\mathrm{F}$ & Body, 1 person & 31.3 & 8.48 & 296 & 3 & 5,491 & 87 & 6.4 \\
\hline $30 \mathrm{Oct}$ & $\mathrm{F}$ & Foot, 6 persons & 31.3 & 8.59 & 251 & 0 & 4,145 & 270 & 150 \\
\hline $30 \mathrm{Oct}$ & $\mathrm{G}$ & Foot, 2 persons & 25.0 & 8.15 & 225 & 0 & 109,000 & 0 & 144 \\
\hline $06 \mathrm{Nov}$ & $\mathrm{H}$ & Foot, 2 persons & 26.8 & 8.49 & 348 & 0 & 5,864 & 2 & 1 \\
\hline $06 \mathrm{Nov}$ & $\mathrm{H}$ & Hand, 2 persons & 26.8 & 8.53 & 357 & 0 & 2,909 & 3 & $<1$ \\
\hline $06 \mathrm{Nov}$ & 1 & Foot, 4 persons & 28.6 & 8.09 & 483 & 0 & 32,700 & 4,290 & $<1$ \\
\hline $06 \mathrm{Nov}$ & $\mathrm{J}$ & Foot, 4 persons & 28.1 & 8.29 & 356 & 0 & 20,000 & 0 & 24 \\
\hline $06 \mathrm{Nov}$ & $\mathrm{K}$ & Foot, 2 persons & 27.8 & 8.32 & 513 & 18 & 30,500 & 0 & $>200$ \\
\hline 06 Nov & $\mathrm{K}$ & Hand, 2 persons & 27.8 & 7.83 & 632 & 13 & 3,955 & 0 & $<1$ \\
\hline $06 \mathrm{Nov}$ & $\mathrm{L}$ & Foot/hand, 1 person & 33.0 & 7.36 & 1,083 & 0 & 18,500 & 6,900 & $>200$ \\
\hline $06 \mathrm{Nov}$ & $\mathrm{L}$ & Body, 1 person & 33.0 & 7.46 & 1,423 & 310 & 20,500 & 1,652 & 2200 \\
\hline $06 \mathrm{Nov}$ & $\mathrm{L}$ & Body, 2 persons & 33.2 & 7.70 & 929 & 1 & 1,500 & 1,908 & 2200 \\
\hline $13 \mathrm{Nov}$ & $M$ & Foot, 1 person & 27.6 & 6.86 & 453 & 0 & 3,182 & 11 & $<1$ \\
\hline $13 \mathrm{Nov}$ & M & Hand, 1 person & 27.6 & 7.82 & 395 & 0 & 355 & 14 & $<1$ \\
\hline $13 \mathrm{Nov}$ & $\mathrm{N}$ & Foot, 2 persons & 28.6 & 6.98 & 416 & 0 & 16,500 & 850 & 1 \\
\hline $13 \mathrm{Nov}$ & $\mathrm{N}$ & Body, 1 person & 28.6 & 8.23 & 333 & 0 & 2,800 & 34 & 14 \\
\hline 13 Nov & 0 & Foot, 2 persons & 27.6 & 7.74 & 218 & 0 & 44,000 & 11 & 2 \\
\hline 14 Nov & $\mathrm{P}$ & Foot, 1 person & 27.8 & 8.11 & 470 & 0 & 100 & 0 & 88 \\
\hline \multicolumn{3}{|c|}{ Minimum values } & 25.0 & 6.86 & 218 & 0 & 32 & 0 & $<1$ \\
\hline \multicolumn{3}{|c|}{ Maximum values } & 33.2 & 8.59 & 1,423 & 310 & 109,000 & 6,900 & $>200$ \\
\hline \multicolumn{3}{|c|}{ Median values } & 28.4 & 8.12 & 432 & 0 & 11,182 & 11 & 33 \\
\hline
\end{tabular}

IE: intestinal enterococci; MPN: most probable number.

\section{Results}

\section{Participants and samples}

Fifteen companies positively responded to the request to participate in the study, a sixteenth company was included through intervention of the local public health service. The sixteen participating companies included wellness centres $(n=4)$, beauty salons $(n=1)$, and companies that solely offered fish spa treatment $(n=11)$. A total of 24 samples were collected: 15 samples from foot spas, five samples from body spas, three samples from hand spas, and one sample from a combined hand-foot spa. None of the fish spas had visible dirt on the spa walls, and therefore swab sampling of the spa walls was not done.

\section{Physical-chemical water quality parameters}

The water temperature in the spas ranged from 25.0 to $33.2^{\circ} \mathrm{C}$, with a median of $28.4^{\circ} \mathrm{C}$ (Table 1 ). In body spas, the water temperature was generally higher than in foot and hand spas. In four of five body spas, the water temperature was above $31^{\circ} \mathrm{C}$. The $\mathrm{pH}$ value of the fish spa water ranged from 6.9 to 8.6 , with a median value of 8.1. In all fish spas, water turbidity values of o.0o Formazine Turbidity Units (FTU) were measured, indicating that the turbidity was very low and below the detection limit of the equipment used. The conductivity ranged from 218 to $1,423 \mu \mathrm{S} / \mathrm{cm}$, with a median of $432 \mu \mathrm{S} / \mathrm{cm}$. The highest conductivity values were exclusively found in the three spas of one company (Table 1).

\section{Microbiological water quality}

In most fish spas, faecal contamination based on the faecal indicator parameter intestinal enterococci was limited (Table 1 ). The E. coli analyses were seriously hampered by abundant growth of Plesiomonas shigelloides, which may have masked E. coli colonies. We therefore consider the $E$. coli data unreliable. Aeromonas spp. were present in all samples from all 
TABLE 2

Water treatment and management in 16 fish spa companies, the Netherlands, 2012

\begin{tabular}{|c|c|c|}
\hline \multirow{2}{*}{ Parameter/management } & \multicolumn{2}{|c|}{ Number of companies } \\
\hline & Yes & No \\
\hline Water filter present & 16 & 0 \\
\hline Water filter per fish spa & 13 & 3 \\
\hline One water filter for several fish spas & 3 & 13 \\
\hline UVC treatment of the water only & 5 & 11 \\
\hline Ozone treatment of the water only & 4 & 12 \\
\hline UVC and ozone treatment of the water & 6 & 10 \\
\hline $\begin{array}{l}\text { Neither UVC nor ozone treatment of the } \\
\text { water }\end{array}$ & 1 & 15 \\
\hline Monitoring of water temperature & 15 & 1 \\
\hline Microbiological water testing & 5 & 11 \\
\hline Keeping a log of water quality & 11 & 5 \\
\hline Complete water replacement ${ }^{\mathrm{a}}$ & 6 & 9 \\
\hline Partial water replacement ${ }^{b}$ & 9 & 6 \\
\hline $\begin{array}{l}\text { No water replacement, only } \\
\text { replenishment }\end{array}$ & 1 & 15 \\
\hline
\end{tabular}

UVC: ultraviolet light C.

a Once to twice a week.

b Daily to once to twice a week, for 10 to $80 \%$.

fish spas, although in varying numbers, ranging from 32 to $1.10^{5}$ colony forming units (CFU) per $100 \mathrm{~mL}$ (Table 1). The median value of $1.10^{4} \mathrm{CFU}$ per $100 \mathrm{~mL}$ indicates that most numbers were on the high end of the range.

$P$. aeruginosa was detected in 18 of the 24 examined fish spas, while in six of 24 spas the most probable number was below the Pseudalert lowest detection limit of 1 per $100 \mathrm{~mL}$. In four of the 18 positive spas, the most probable number was above the Pseudalert highest detection limit of 200 per $100 \mathrm{~mL}$ (Table 1 ). MALDI-TOF confirmed the presence of $P$. aeruginosa in positive wells, in those samples $(n=4)$ where it was applied.

Vibrio spp. were present in 16 of 24 fish spas; in positive samples, the Vibrio numbers ranged from two to 6,900 CFU per $100 \mathrm{~mL}$, but most concentrations were low (Table 1). Species identification with MALDI-TOF demonstrated the presence of $V$. cholerae in all positive fish spas. PCR of the toxR and $c t x A$ genes according to Schets et al. [15] confirmed that the isolates were $V$. cholerae and demonstrated that they were nontoxigenic. $V$. vulnificus was found in one full body spa only. PCR of the vvhA gene according to Canigral et al. [16] confirmed the MALDI-TOF identification.

Incubated samples could only be read for the presence of rapid growing mycobacteria (RGM). Reading the plates for the presence of slow growing mycobacteria was not possible due to the growth of large amounts of disturbing background flora. RGM were present in 23 fish spas; the incubated sample from the 24 th fish spa could not be read due to overgrowth by fungi. Mycobacterium species that were frequently found included $M$. fortuitum $\left(\mathrm{n}_{\text {fish spa }}=21\right), M$. conceptionense/M. senegalense $\left(\mathrm{n}_{\text {fish spa }}=16\right), M$. abscessus $\left(\mathrm{n}_{\text {fish spa }}=15\right)$, and M. chelonae $\left(\mathrm{n}_{\text {fish spa }}=13\right)$. Less abundant were other $M$. chelonae complex isolates $\left(\mathrm{n}_{\text {fish spa }}=7\right), M$. abscessus subsp. bolletii $\left(\mathrm{n}_{\text {fish spa }}=8\right)$, and M. phocaicum $\left(\mathrm{n}_{\text {fish spa }}=6\right)$. $M$. alvei, M. peregrinum, M. porcinum, M. wolinski, and three novel, yet unknown environmental mycobacteria, were only incidentally isolated.

\section{Management}

The investigated companies had fish spas from various suppliers, whereas some of them constructed their own spas. Most companies purchased the fish from the same supplier.

All companies filtered the fish spa water, using biological filters with zeolite; the majority had one filter per fish spa installed. Additionally, most companies treated the water with ultraviolet light C (UVC), ozone or both. Almost all companies checked the water temperature on a regular basis, and many of them used a test kit designed for aquarium and pond owners to test a basic set of chemical parameters, including $\mathrm{pH}$ value, hardness, ammonia, nitrite, nitrate, phosphate, iron, and copper. Keeping a log was not a standard procedure. Five of the 16 companies had the microbiological water quality checked by a laboratory. Refreshment policies varied from total replacement of the water once to twice a week, to partial replacement of the water with a daily to weekly frequency (Table 2 ).

\section{Discussion}

All bacteria the fish spa water was tested for, were detected, although not in all spas and in varying concentrations. Whether or not Aeromonas spp. Vibrio spp., $P$. aeruginosa or RGM were found, could not be related to a specific type of spa (foot, hand, or body), a specific water treatment process (filtration with UVC, ozone or both), or a specific regime of water refreshment (total or partly, with varying frequency). Physicalchemical parameters did also not relate to presence or absence of bacteria or high or low bacterial counts. It is plausible that the small number of fish spas contributed to the inability to determine a possible correlation with microbiological water quality. Also, the presence of bacteria may depend on occasional contamination of the water by clients and the subsequent expansion of the contamination for prolonged time periods. Most owners could, however, not provide clear figures on spa use in terms of number of users per day; so a 
relation between intensity of fish spa use and microbiological water quality could not be established.

When comparing the Vibrio spp. concentration in fish spas (o-6,900 CFU/100 ml, median $11 \mathrm{CFU} / 100 \mathrm{ml}$ ) with the numbers detected in various surfaces water in the Netherlands during summer (o - 4.2.105 MPN/100 ml, median $37 \mathrm{MPN} / 100 \mathrm{ml}$ [15], the numbers in fish spas were mostly lower, or sometimes in the same order of magnitude, even though the water temperature in fish spas was ca 5 to $10^{\circ} \mathrm{C}$ higher than the surface water temperature during summer [15]. Current Vibrio spp. concentrations in surface water led to a limited number of reported cases of illness in the Netherlands, which were mostly cases of ear complaints as a result of $\mathrm{V}$. alginolyticus infections [15]. This suggests that the Vibrio spp. numbers in fish spas do not pose a major health risk. However, the presence of $V$. cholerae non- $0_{1} /$ 0139 and $V$. vulnificus, which are a well-known cause of wound infections in humans $[15,17]$, may pose a risk for people with a damaged skin. Moreover, the high water temperatures in fish spas can allow Vibrio spp. to proliferate to numbers higher than those observed in the sampled fish spas, resulting in an increased risk.

In chlorinated pools, $P$. aeruginosa should be absent in $100 \mathrm{ml}$ samples of the pool water [18]; a requirement that was not met in $75 \%$ of the fish spas. There are no requirements for $P$. aeruginosa in recreational surface waters. Comparing the $P$. aeruginosa concentrations in fish spas (range $1-178 \mathrm{MPN} / 100 \mathrm{ml}$, median $33 \mathrm{MPN} / 100 \mathrm{ml}$ ) with those previously found in Dutch surface waters, generally shows lower concentrations in the latter (o - $9 \mathrm{CFU} / 100 \mathrm{ml}$ ) [19], also in recreational water related to outbreaks of otitis externa ( 0.4 CFU/100 $\mathrm{ml}$ ) [20]. In the swimming pool environment, $P$. aeruginosa commonly causes folliculitis through infection of disrupted follicles, and although dose response relationships for dermal exposure are unclear, the suggested levels of concern for healthy individuals are $>10^{5}$ per $100 \mathrm{ml}$ [21]. Concentrations in that range were not found in the examined fish spas, suggesting that the health risk related to $P$. aeruginosa in fish spas is limited for people with an intact skin. $P$. aeruginosa may however pose a greater risk for people with a damaged skin, and in spas where numbers largely exceed $10^{5}$ per $100 \mathrm{ml}$.

Aeromonas spp. are ubiquitous in the aquatic environment, in a broad range of concentrations [22], and have also been detected in all examined fish spas. Concentrations in fish spas were in the order of magnitude as those typical for rivers receiving sewage discharge [22]. A health risk from the isolated Aeromonas spp. cannot be fully ruled out, but it may be limited for healthy individuals with an intact skin and no underlying disease or reduced immunity, since human skin and soft tissue infections with Aeromonas spp. are commonly associated with wounds after water related trauma, or occur in persons with underlying disease [23].
RGM, that have been detected in all examined fish spas, are known environmental opportunistic pathogens that are increasingly recognised as causative agents of human and fish disease, both in sporadic cases and outbreaks $[24,25]$. Their transmission to humans from an environmental source, with subsequent clinical disease, is however rarely proven, except for cases in hospital settings [24]. Most of the species isolated from fish spas have previously been found as the cause of illness in immune competent persons after exposure to various water sources, including whirlpool footbaths in a nail salon (M. fortuitum) [26], a fish tank after contact with broken glass ( $M$. senegalense) [27], and therapy pool water (M. phocaicum) [28]. In the Netherlands, RGM have been isolated from tap and shower water without a direct link to illness [14]. M. chelonae, $M$. abscessus, and $M$. fortuitum are frequently found in clinical samples whereas the other species recovered from fish spas are less frequently observed [25]. The three yet unclassified environmental Mycobacterium species have not previously been isolated from human samples in the Netherlands and have not been found in the BLAST database.

The low level of faecal contamination confirmed the expected low input of intestinal enterococci with human faeces through hands and feet, as well as the limited contribution of the fish [29]. Dilution and regular cleaning policies probably enhance these low levels. A higher level of faecal contamination could be expected in full body spas, but was not observed. Pl. shigelloides, which appeared to be present in most fish spas and hampered the $E$. coli detection, is naturally present in warm surface water and causes human gastroenteritis [30]. Pl. shigelloides is known to disturb $E$. coli enumeration in samples from warm surface waters while using the Rapid Test in ISO 9308-1:2000 [30]. Although the presence of $P l$. shigelloides in fish spas was not foreseen, it appeared that the bacterium is often part of the microbial flora in aquariums [31].

This study provided insight in the microbiological condition of fish spa water, albeit the number of data are too limited to suggest ranges for acceptable microbiological contamination. Fish spas do, however, require their own set of microbiological parameters and guide values. Swimming pool and recreational water guidelines are not particularly appropriate, since they focus on an environment with a residual effect of disinfectants, or apply to surface waters with different contamination sources.

The detected concentrations of Aeromonas spp., Vibrio spp., and $P$. aeruginosa in the water of the examined fish spas, in combination with the health implications of these bacteria at such levels, and the detected Mycobacterium spp. and their health implications, suggest a low health risk from fish spas. The data from this study support the opinion of Health Protection Agency (now Public Health England) and the French 
Agency for Food, Environmental and Occupational Health and Safety (ANSES) that the health risk from using fish spas is limited for healthy people with an intact skin and no underlying disease. Persons with underlying disease affecting the immune system, such as diabetes, and skin conditions, such as psoriasis and eczema, and persons with a damaged skin, may be at a greater risk. Transmission of infection through ingestion of intestinal pathogens in contaminated water is of limited importance in hand and foot spas, but it may play a role in body spas. Moreover, head immersions in body spas, may lead to ear infections with $P$. aeruginosa or Vibrio spp. In all spa types, pathogens can be transmitted through hand-mouth contact. This transmission route is likely to be more relevant when the water is heavily contaminated [32].

In addition to establishing microbiological guidelines for fish spas, drafting a code of practice on hygiene in fish spas and risk communication to clients is recommended.

\section{Acknowledgments}

The authors thank all owners and employees of the involved companies for their participation. John Klippel (province of South-Holland), Mariëlle Dirven (Public Health Service Rotterdam-Rijnmond), and Jerry van Druten (province of Overijssel) are acknowledged for their help in sampling. Miranda Kamst (RIVM) is acknowledged for assisting the mycobacteria analyses. The authors thank Olga Haenen (Central Veterinary Institute of Wageningen University), Joke van der Giessen, Corien Swaan, Thijs Veenstra (all from RIVM) for their contribution to this work. This work was funded by the Netherlands Food and Consumer Safety Authority (NVWA).

\section{Conflict of interest}

None declared.

\section{Authors' contributions}

FMS and HHvdB designed the study, HHvdB and RdZ carried out microbiological analyses, FMS performed data analysis and drafted the manuscript, FMS, DvS and AMdRH interpreted data, and all authors reviewed and revised the first and final drafts of this manuscript.

\section{References}

1. Health Protection Agency (HPA). Guidance on the management of the public health risks from fish pedicures. London: HPA. 31 Aug 2011. Available from: https://www.gov.uk/government/ uploads/system/uploads/attachment_data/file/322420/Fish_ Spa_guidance.pdf

2. Grassberger M, Hoch W. Ichthyotherapy as alternative treatment for patients with psoriasis: a pilot study. Adv Acc Public eCAM. 2006; 3(4):483-488.

3. Ozçelik S, Polat HH, Akyol M, Yalçin AN, Ozçelik D, Marufihah M. Kangal hot spring with fish and psoriasis treatment. J Dermatol. 2000;27(6):386-90. PMID:10920584

4. Gronquist D, Berges JA. Effects of aquarium-related stressors on the zebrafish: a comparison of behavioral, physiological, and biochemical indicators. J Aquat Anim Health. 2013;25(1):5365. http://dx.doi.org/10.1080/08997659.2012.747450 PMID:23339327

5. Ramsay JM, Watral V, Schreck CB, Kent ML. Husbandry stress exacerbates mycobacterial infections in adult zebrafish, Danio rerio (Hamilton). J Fish Dis. 2009;32(11):931-41. http://dx.doi. org/10.1111/j.1365-2761.2009.01074.x PMID:19531062

6. Majtán J, Černy J, Ofúkaná A, Takáč P, Kozánek M. Mortality of therapeutic fish Garra rufa caused by Aeromonas sobria. Asian Pac J Trop Biomed. 2012;2(2):85-7. http://dx.doi.org/10.1016/ S2221-1691(11)60197-4 PMID:23569873

7. Verner-Jeffreys DW, Baker-Austin C, Pond MJ, Rimmer GSE, Kerr $R$, Stone D, et al. Zoonotic disease pathogens in fish used for pedicure. Emerg Infect Dis. 2012;18(6):1006-8. http://dx.doi. org/10.3201/eid1806.111782 PMID:22608013

8. Agence nationale de sécurité sanitaire de l'alimentation, de l'environnement et du travail (ANSES). Avis de l'Agence de sécurité sanitaire de l'alimentation de l'environnement et du travail relatif à l'analyse des risques sanitaires liés à pratique d'immersion des pieds dans un bac d'eau contenant des poisons de l'espèce Garra rufa. Avis de L'Anses Saisine no 2012-SA-0098. [Opinion of the French Agency for Food, Environmental and Occupational Health and Safety analysing the health risks of immersing feet in water tanks containing fish of the species Garra rufa. ANSES opinion. Referral no 2012-SA-0098]. 1 Feb 2013. French. Available from: https://www.anses.fr/sites/default/files/documents/ EAUX2012sa0098.pdf

9. Hoge Gezondheidsraad. Advies van de hoge gezondheidsraad nr. 8773: Fish pedicure - Ichtyotherapie. [Advice from the Superior Health Council no. 8773: Fish pedicure Ichtyotherapy]. 6 Mar 2013. [Dutch]. Available from: http:// health.belgium.be/internet2Prd/groups/public/@public/@shc/ documents/ie2divers/19086137.pdf

10. Höller C, Hörmansdorfer S, Schramek N, Moritz J. [Sanitary, veterinary and legal aspects on the use of Kangal fish on humans]. Hyg Med. 2013;38(7-8):306-11. [German].

11. Havelaar AH, During M, Versteegh JF. Ampicillin-dextrin agar medium for the enumeration of Aeromonas species in water by membrane filtration. J Appl Bacteriol. 1987;62(3):27987. http://dx.doi.org/10.1111/j.1365-2672.1987.tbo2410.x PMID:3597206

12. Dieckmann R, Strauch E, Alter T. Rapid identification and characterization of Vibrio species using whole-cell MALDI-TOF mass spectrometry. J Appl Microbiol. 2010;109(1):199-211. PMID:20059616

13. Adékambi T, Colson P, Drancourt M. rpoB-based identification of nonpigmented and late-pigmenting rapidly growing mycobacteria. J Clin Microbiol. 2003;41(12):5699-708. http:// dx.doi.org/10.1128/JCM.41.12.5699-5708.2003 PMID:14662964

14. van Ingen J, Blaak H, de Beer J, de Roda Husman AM, van Soolingen D. Rapidly growing nontuberculous mycobacteria cultured from home tap and shower water. Appl Environ Microbiol. 2010;76(17):6017-9. http://dx.doi.org/10.1128/ AEM.00843-10 PMID:20639378

15. Schets FM, van den Berg HHJL, Marchese A, Garbom S, de Roda Husman AM. Potentially human pathogenic vibrios in marine and fresh bathing waters related to environmental conditions and disease outcome. Int J Hyg Environ Health. 2011;214(5):399-406. http://dx.doi.org/10.1016/j. ijheh.2011.05.003 PMID:21664866

16. Cañigral I, Moreno Y, Alonso JL, González A, Ferrús MA. Detection of Vibrio vulnificus in seafood, seawater and wastewater samples from a Mediterranean coastal area. Microbiol Res. 2010;165(8):657-64. http://dx.doi.org/10.1016/j. micres.2009.11.012 PMID:20106642

17. Austin B. Vibrios as causal agents of zoonoses. Vet Microbiol. 2010;140(3-4):310-7. http://dx.doi.org/10.1016/j. vetmic.2009.03.015 PMID:19342185

18. Overheid.nl. Wet Hygiëne en Veiligheid Badinrichtingen en Zwemgelegenheden. [Law on the hygiene and safety of bathing facilities and beaches]. Staatsblad. 2000. [Dutch] Available from: http://wetten.overheid.nl/BWBRoo02660/ geldigheidsdatum_06-05-2015

19. Schets FM, van den Berg HHJL, Lodder WJ, Docters van Leeuwen AE, de Roda Husman AM. Pathogene microorganismen in zwemwater in relatie tot indicatoren voor fecale verontreiniging. [Pathogenic micro-organisms in recreational water related to indicators of faecal pollution]. 9 Jun 2006. RIVM report 330400001 . Bilthoven: National Institute for Public Health and the Environment (RIVM). [Dutch]. Available from: http://www.rivm.nl/dsresource?objectid=rivmp:13343\&type $=0$ rg\&disposition=inline\&ns_nc=1

20. van Asperen IA, de Rover CM, Schijven JF, Oetomo SB, Schellekens JF, van Leeuwen NJ, et al. Risk of otitis externa after swimming in recreational fresh water lakes containing Pseudomonas aeruginosa. BMJ. 1995;311(7017):1407-10. http:// dx.doi.org/10.1136/bmj.311.7017.1407 PMID:8520277

21. Price D, Ahearn DG. Incidence and persistence of Pseudomonas aeruginosa in whirlpools. J Clin Microbiol. 1988;26(9):1650-4. PMID:3141463 
22. World Health Organization (WHO). Aeromonas. In: Guidelines for drinking-water quality, 2nd ed. 2002; Addendum:

Microbiological agents in drinking water. Geneva: WHO. 2002. Available from: http://www.who.int/water_sanitation_health/ dwq/admicrob1.pdf

23. Janda JM, Abbott SL. The genus Aeromonas: taxonomy, pathogenicity, and infection. Clin Microbiol Rev. 2010;23(1):3573. http://dx.doi.org/10.1128/CMR.00039-09 PMID:20065325

24. De Groote MA, Huitt $G$. Infections due to rapidly growing mycobacteria. Clin Infect Dis. 2006;42(12):1756-63. http:// dx.doi.org/10.1086/504381 PMID:16705584

25. van Ingen J, Boeree MJ, Dekhuijzen PNR, van Soolingen D. Environmental sources of rapid growing nontuberculous mycobacteria causing disease in humans. Clin Microbiol Infect. 2009;15(10):888-93. http://dx.doi.org/10.1111/j.14690691.2009.03013.x PMID:19845700

26. Winthrop KL, Abrams M, Yakrus M, Schwartz I, Ely J, Gillies D, et al. An outbreak of mycobacterial furunculosis associated with footbaths at a nail salon. N Engl J Med. 2002;346(18):1366-71. http://dx.doi.org/10.1056/ NEJMoa012643 PMID:11986410

27. Talavlikar R, Carson J, Meatherill B, Desai S, Sharma M, Shandro $C$, et al. Mycobacterium senegalense tissue infection in a child after fish tank exposure. Can J Infect Dis Med Microbiol. 2011;22(3):101-3. PMID:22942887

28. Ben Salah I, Adékambi T, Drancourt M. Mycobacterium phocaicum in therapy pool water. Int J Hyg Environ Health. 2009;212(4):439-44. http://dx.doi.org/10.1016/j. ijheh.2008.10.002 PMID:19201259

29. Cahill MM. Bacterial flora of fishes: A review. Microb Ecol. 1990;19(1):21-41. http://dx.doi.org/10.1007/BF02015051 PMID:24196252

30. Medema G, Schets C. Occurrence of Plesiomonas shigelloides in surface water: relationship with faecal pollution and trophic state. Zentralbl Hyg Umweltmed. 1993;194(4):398-404. PMID:8397688

31. Smith KF, Schmidt V, Rosen GE, Amaral-Zettler L. Microbial diversity and potential pathogens in ornamental fish aquarium water. PLoS ONE. 2012;7(9):e39971. http://dx.doi.org/10.1371/ journal.pone.0039971 PMID:22970112

32. de Man H, van den Berg HHJL, Leenen EJTM, Schijven JF, Schets FM, van der Vliet JC, et al. Quantitative assessment of infection risk from exposure to waterborne pathogens in urban floodwater. Water Res. 2014;48:90-9. http://dx.doi. org/10.1016/j.watres.2013.09.022 PMID:24095592 